\title{
Religious Syimbols and the Maintenance of Social Harmony in Lombok, West Nusa Tenggara
}

\author{
Fathurrahman Muhtar \\ Pascasarjana Universitas Islam Negeri Mataram, Indonesia \\ fathurrahmanmuhtar@uinmataram.ac.id
}

\begin{abstract}
Abstrak
Simbol telah menjadi bagian penting dari agama-agama di dunia karena dapat merepresentasikan nilai, gagasan dan peristiwa keagamaan. Penelitian ini bermaksud ingin mengkaji makna simbol-simbol keagamaan di Lombok, Nusa Tenggara Barat, dan perannya dalam menjaga kerukunan masyarakat beragama di wilayah tersebut. Penelitian ini bersifat kualitatif-interpretatif dengan teknik pengumpulan data melalui wawancara, observasi, dan dokumentasi. Selanjutnya, analisis data dilakukan dengan desain grounded theory. Hasil penelitian ini menunjukkan bahwa simbol-simbol pluralisme agama tampak pada Pura Meru (di sebelah Masjid Nurul Falah), pada patung-patung berbagai tokoh agama di Pura Mayura, dan pada Pura Lingsar yang memiliki sebuah bangunan kuno bernama Kemalik. Simbol-simbol tersebut diakui sebagai milik bersama umat Hindu dan Muslim, sekaligus sebagai tempat untuk mendapatkan keberkahan. Ada juga festival Perang Topat (Perang Ketupat) yang merupakan warisan tradisi Muslim dan Hindu dan digunakan sebagai media untuk menumpahkan segala bentuk amarah para pemeluk agama dan kemudian diakhiri dengan berdamai. Simbol-simbol tersebut diyakini mampu menumbuhkan kebersamaan dan kerukunan di Lombok, Nusa Tenggara Barat. Secara umum, keberadaan simbol-simbol keagamaan tersebut telah menjadikan Cakranegara dan Lingsar sebagai tempat yang damai dan terbebas dari konflik agama hingga saat ini.
\end{abstract}

Kata kunci: Hindu, Islam, kerukunan masyarakat, pura, simbol keagamaan, 


\begin{abstract}
Symbols have been a crucial part of all religions in the world for they can represent religious values, ideas, and events. This study seeks to examine the meaning of religious symbols in Lombok, West Nusa Tenggara, and their role in maintaining socio-religious harmony in the region. Qualitative and interpretative in nature, data collection techniques in this study were carried out through interviews, observation, and documentation. Meanwhile, data analysis employed a grounded theory design. The results of this study indicate that the symbols of religious pluralism are visible on the Pura Meru (next to the Nurul Falah mosque), on the statues of various religious figures at the Pura Mayura, and on the Pura Lingsar, a home for an ancient building called Kemalik. These symbols have been recognized as common properties of Hindus and Muslims and as places to get blessings. There is also the Topat War festival which is a legacy of Muslim and Hindu traditions used as a medium to pour out any form of anger among religious adherents and then end with peace. Those symbols are believed to be able to foster togetherness and harmony in Lombok, West Nusa Tenggara. In general, these religious symbols have made Cakranegara and Lingsar peaceful areas free from religious conflicts to date.
\end{abstract}

Keywords: Islam, Hindu, religious symbols, social harmony, temples

\title{
Introduction
}

Various foreign cultures, including Java, Makassar, Bugis, Bali, the Netherlands, and Japan, have conquered Lombok for centuries and influenced the diversity of religions on the island. After the Majapahit Hindu Kingdom of East Java ruled Lombok in the 7th century, Hinduism and Buddhism flourished. Later, in the 13th century, Islam found its way to Lombok, first spread by Javanese Muslim kings. Next, Makassar arrived in East Lombok in the 16th century and founded the Selaparang Kingdom. Around the 17th century, the Kingdom of Bali from Karangasem occupied the region of West Lombok. The Balinese government demonstrated great wisdom and tolerance by allowing the Sasak to obey their own religion's teachings (Erni Budiwanti, 2000: 9).

With the penetration of such foreign influences, religious symbols can naturally exist in Lombok due to the power of belief, most notably due to the mosque adjacent to Pura Meru in the Cakranegara district serving as a symbol of religious pluralism in Lombok, West Nusa Tenggara. Pura Meru is adjacent to the Nurul Falah Mosque in Mataram City.

Islam and Hindu relations in Lombok strengthened after the King of Bali, together with his brother named Anak Agung Gede Ngurah Karang Asem, yearned for mutual respect for Hindus and Muslims in Lombok. To realize this desire, Prince Raja Bali married a noble princess of Datuk Selaparang's 
descent named Dende Aminah (also known as Denda Nawangsasih), then remarried to another Sasak woman named Dende Fatimah (Anak Agung Ketut Agung, 1991: 183). To strengthen the King of Bali's relationship with penghulu (a religious figure), the king gave him pecatu land to support his position as the leader of a religious institution (mosque) in a village. Pecatu for this religious institution is called waqf land or buktin misigit (I Gede Parimartha, 2011: 50).

Later, since the early 17th century, the Balinese authority has been known in West Lombok. The relationship between the ruler of Bali and the Sasak people in power is very harmonious. Sasak farmers who adhere to Telu's version of Islam attend religious celebrations and prayers at the same place of worship (Alfons Van der Kraan: 2009: 6).

Bali's Islam and Hindu relations were very close, mainly after Ratu Agung married a Sasak Muslim woman. After that, Sayyid Abdullah bin Abdoerrahim Al-Kadrie Djaelani was appointed as the advisor to the king by the great queen. Raja Agung was able to marry Dende Aminah with the help of Sayyid Abdullah. Later, the great queen changed various royal policies by building a mosque in Ampenan, which helped Sasak people ascend the hajj to Makkah. In the 1880 s and 1890 s, the King of Lombok even established a kind of representative in Jeddah (Saudi Arabia) to help Muslims from East Lombok and Ampenan perform hajj. Haji Abdul Majid, a delegate from Lombok, was the figure in command (Anak Agung Ketut Agung, 1991: 189). He is the father of Tuan Guru H. Muhammad Zainuddin Abdul Majid, a national hero from Lombok, the founder of Nahdlatul Wathan, and the amirul hajj of the State of Eastern Indonesia (NIT) in 1948-1949.

The relationship between the King of Bali and the Islamic society of Lombok is visible from various symbols attached to Pura Lingsar, Pura Meru, and Pura Mayura. Pura Lingsar, a Hindu and Muslim temple founded around $1714 \mathrm{AD}$, is a sacred temple. It has two smaller holy temples and is the only place where Hindus, Buddhists, and Muslims pray for prosperity, fertility, rain, and health, among others (NTB Cultural and Tourism Office, 2015). Lombok also has Hindu-scented Islamic rituals, implying a syncretic relationship between Islam and Hinduism (Hasan Muarrif Ambary, 1998: 268). Besides, Lombok's past reveals that these symbols arose from the island's fight for religious dominance, such as the Topat War at Pura Lingsar, which demonstrated Hinduism's superiority over Islam. 
The presence of two religions in one region is also due to a water source called Kemalik located in the center of Pura Lingsar. In areas with ample water supplies, Islam and Hinduism will usually coexist. In fact, most of Lombok's temples are built near springs, such as in Pura Mayura, Narmada Park's awet muda springs, and in Pura Meru. Water is revered both in Islam and Hinduism as a medium for purification and as a source of life.

The symbols of pluralism have colored the religious culture in Lombok until now and been a practice that has not been disrupted by the values of each faith, despite the fact that Lombok is known as the 'Island of a Thousand Mosques, and the majority of the population is Muslims. Such symbols seem to demonstrate how harmonious and plural the people of Lombok are. Harmony was taught to the people of Lombok by their forefathers and mothers. Co-existence amongst religious people seems to be difficult to achieve if there are no unifying religious icons. Hence, the icons have become a part of the tradition that the government and the NTB society are protecting.

Several religious studies concerning Lombok have concentrated solely on the Topat War in Pura Lingsar. These studies seem to have neglected other factors that became symbols for Muslims and other religions to coexist peacefully. This present study lists some important places that Muslims, Hindus, Christianity, Khonghucu, and Buddha use as symbols of peace. Such sites include Pura Mayura, Pura Meru, Nurul Falah Mosque, Pura Lingsar, and several symbols in them, such as the bathing place named Pancuran Songo and Kemalik considered sacred by both Muslims and Hindus. This study also confirms that internal dimensions of a religion are not the root of conflict in Lombok; the conflict is mostly caused by rather political, economic, and cultural factors. Religion is not the cause of conflict, though it is frequently linked when disputes occur.

The close relationship between Islam and other religions is influenced by various factors, i.e. from history, genealogy, and state policy to public participation and religious-cultural festivals. Indeed, Muslims and Hindus in Lombok inherit historical practices and uphold cultures that help them coexist. They share temples for interfaith celebrations. There is a historical narrative of good relations between religions and genealogies in villages and cities in maintaining their daily interactions in towns and cities. Tensions occur when these cultural relationships do not exist or continue to vanish due to rapid development, urbanization, population growth, competition for job openings, and other resources (Abdun Natsir: 2020). 
According to Harnis, since 1988, religious celebrations in Pura Lingsar have been used to legitimize political power. However, since Tuan Guru Bajang Zainul Majdi, the celebration at Pura Lingsar has been used to symbolize Islamic and Hindu religious unity in Lombok. The centralized power of Lingsar has made various elements of society preserve the site and festival in Pura Lingsar, such as the springs and traditions of Topat War (Harnis, 2017: 81). On that basis, the festival Topat War (Topat War) got legitimacy from the religious leaders; that is, Topat War in Pura Lingsar is not contrary to the teachings of Islam. However, Suprapto in his research mentioned that Muslim puritans have recently criticized and banned Muslim participation in the festival of Topat War. They believe that integrating religious rituals with tradition is a bid'ah or heresy (Suprapto, 2017: 77). Based on these assumptions, the author poses two research questions. First, what are the religious symbols that exist in Lombok? Second, what do they mean, and how do they affect socio-religious life in Lombok?

\section{Methods}

This research used a qualitative approach with in-depth interviews, observation, and documentation as the data collection technique. This technique is the fundamental method of research (Marshall and Rossman, 1989: 79), with which the researcher interviewed several informants, observed the field directly, saw the object under investigation, and observed the social life around the Pura Meru, Nurul Falah Mosque, Pura Mayura, and Pura Lingsar.

He also gathered information from historical documents about the history of the Pura Mayura and Pura Lingsar's gardens found in the temples' entrances. The data from interviews, observations, and documents were then interpreted and analyzed to reveal the variety of conditions and situations related to the research objects. Finally, the results of the interpretation and analysis end up in conclusion.

\section{Various Kinds of Religious Symbols in Lombok}

This study focuses on the relationship of interreligious communities in Lombok, West Nusa Tenggara, by using symbolic interactionism theory. In that theory, symbols are understood as the product of the ancestors' interpretations articulated in language. 
Later, ideas that are passed down from generation to generation are documented in the text. Through symbols, one can imagine what it will be like to survive in the past or the future (George Ritzer, 2008: 395).

Meanwhile, religion is a sacred emblem that synthesizes society's ethos, which includes a nation's tone, character, way of life, and perception of things ( Clifford Geertz: 1993). Here, religious symbols can nurture or compress moods, emotions, and values. The symbols may refer to specific locations, people, or historical events. They are emotional expressions as well as assumptions taken from various religious and historical pieces of shreds of evidence (Bryan S. Turner, 2012). Men created various symbols to reflect their beliefs in faith, social life, and culture. In turn, those symbols serve to form a strong bond of togetherness, love, and respect for each other. The following are the various kinds of symbols used as religious adhesives in Lombok.

\section{Nurul Falah Mosque and Pura Meru}

Nurul Falah Mosque and Pura Meru are located in the Cakranegara subdistrict, Mataram municipality. They are right next to the Mayura Park complex. In the past, the center of the Cakranegara administration was conceived to be a unity of two temples. Pura Meru is on the south side of the lane, while Mayura Park is on the north side. Both have a purpose and a shared history (field observations: 2018). Pura Meru is the largest Pura in Lombok, where a high gate with red brick nuances and three soaring temple peaks are seen from the driveway. The mosque's dome is found next to the Pura, and a church is located across the street from Pura Mayura.

The sacred area of the Pura is divided into three sections, each separated by a brick wall, and there are three doors to access the following site when entering the temple grounds. Each entrance represents one of the three existing temples dedicated to Brahma, Shiva, and Vishnu. Brahma and Shiva's doors are only opened once a year, on September 23, during the Piodalan festival in commemorating the temple's establishment in 1720.

Pura Meru has been around since 1720, when Anak Agung founded it on an area of one hectare. Meanwhile, the 'Langgar' next to the Pura serves as a place of prayer for Muslim traders in the Klodan Market, established in 1975. It was built in the Hindu land of Penengah Kute (interview with Gede Remba, 2018). 


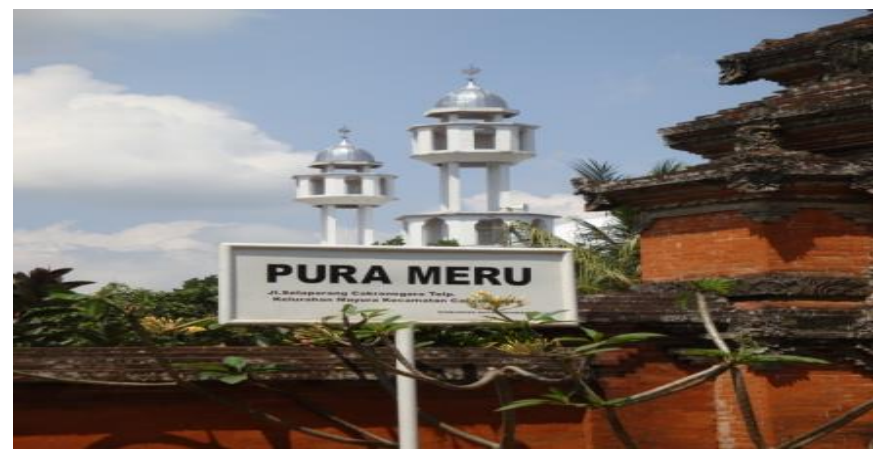

(Picture 1: Nurul Falah Mosque and Pura Meru)

The majority of people around the mosque are Balinese Hindus. The village in which the mosques is located is called Klodan Village and has about 180 families. According to Remba, the mosque was originally a 'Langgar' (musholla), a place of prayer for the Cakranegara Market's traders. It became a place of worship because, in the past, waterways originating from Mayura flowed through the Pura Meru. In addition, most people in the region believe that the mosque belongs to an Arab named Abdullah or better known as Abah Dolah. According to him, the shape of the mosque is not what it is today (Jaz'in Hamid: 2018).

The presence of local people in daily life has revealed the relationship between the Islamic community around Nurul Falah Mosque and Pura Meru. Cakranegara Market connects the majority of people in the area with the mosques and temples. Thus, the existence of temples and mosques shows the closeness of Muslims and Hindus in their social interactions. The two places of worship become an attraction and adhesive that promote interreligious unity. Life around the mosque and Pura Meru is a form of togetherness between Muslims and Hindus that look after each other and support each other (interview with Muhammad, 2018). A Klodan villager name Nyoman stated: "I see the existence of temples and mosques as not a barrier for Hindus to worship. We, the Hindus and Muslims, live in harmony, help each other, and keep the mosque and the Pura. The Hindus respect the Muslims when adhan is observed. Similarly, the Muslims do not feel disturbed by the Hindus" (interview with Nyoman, 2018).

According to Shahdan Ilyas, chairman of the Forum for Religious Harmony (FKUB), a place of worship adjacent to other religious places of worship in Cakranegara serves as a symbol of religious harmony. It is built on the awareness of the surrounding community about the importance of 
cooperation in social activities. These symbols remain firmly rooted in a harmonious and peaceful spiritual existence (interview with Shahdan Ilyas, 2018).

\section{Pura Mayura and Statues of Various Religious Figures}

Mayura Park is regarded as a symbol of Hindu, Islam and Khonghucu's pluralism. According to the local people, the three religions met in the park to discuss different social issues. A statue dressed in hajj depicting an Islamic figure, a statue dressed in Chinese-style clothing depicting the Khonghucu religion, and a statue depicting a Hindu figure refers to Hinduism (field observation, 2018). Once the Forum for Religious Harmony (FKUB) convened a conference of religious leaders from Islam, Hinduism, Christianity, and Hongkhucu. In the conference, Mayura became one of the conference icons of religious peace undertaken by the Hindu king (interview with Muslihun, 2018).
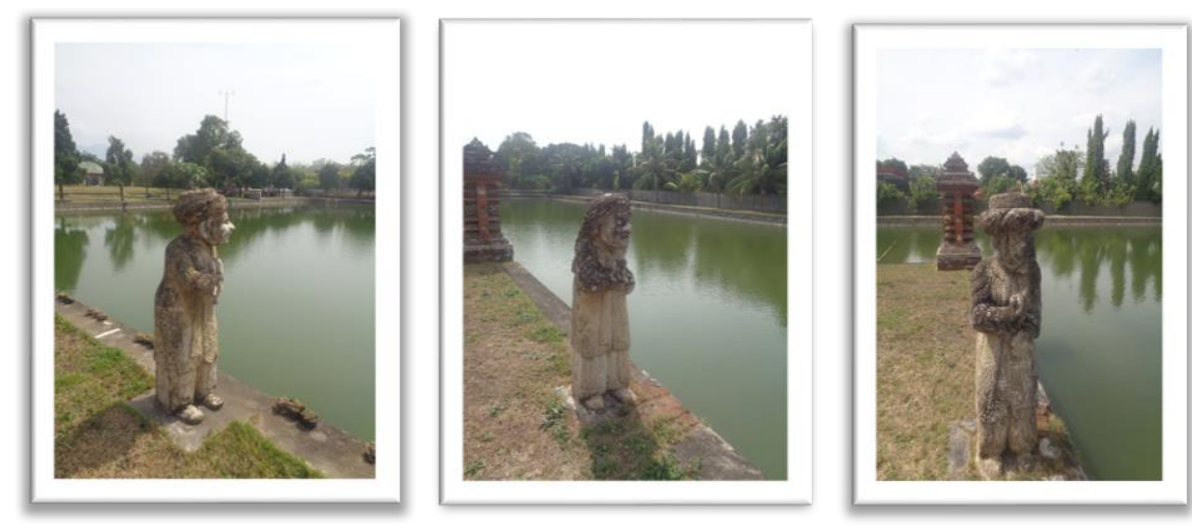

(Picture 2: Statues of Various Religious Figures in Bale Kambang)

Mayura Park was built around 1744 AD by King Anak Agung Made Karangasem during the Kingdom of Bali and is still well preserved on Lombok island. Its structure is covered in Balinese and Javanese designs. Initially, the park was known as Taman Istana Kelepug. Kelepug means 'drop' and refers to the rush of water from a spring in the center of a park's pond. Kelepug Park was once renamed Mayura Water Park after it was rebuilt in 1866. Mayura comes from the Sanskrit word 'mayura,' meaning 'peacock.' According to legend, many snakes roamed the palace garden during the reign of King Anak Agung Ngurah Karangasem, so peacocks was held in captivity to feed on the snakes (Anak Agung Ketut Agung, 1991: 191). 
In the north side of Mayura Park, in the early days of its construction, there was a unique complex built like a pesantren, with a mosque where people learned to read the Qur'an. The main building is named Stambul, in which Sumantri (known as Datuk Pangeran), the king's grandson, converted to Islam. He was the son of Anak Agung Ketut Karangasem, the crown prince (Anak Agung Ketut Agung, 1991: 181). There was also Bale Kambang, a symbol of the judiciary in Rad Kerta's time, standing in the backyard, and complete with a vast pool in the middle of the pond. Around Bale Kambang are Hindu, Muslims (dressed in Arabic robes), Confucian, Buddhist, and Christian statues (field observation, 2018).

\section{Pura Lingsar, Kemalik, and Topat War}

Pura Lingsar has a sacred building (known as Kemali)that has been glorified by the Islamic community named 'Waktu Telu.' At the time of Pujawali ritual, held once a year at Posiamasa (the sixth sasih in either Oktober or November), there was a Topat War between Hindus and Muslims Telu. This ritual became a symbol of inner bonding and reinforced their conviction that the rice paddies and sarwa tinandur would become fertile following the Topat War. According to Sasak legend, the Kemali is where Datuk Selaparang vanished during the battle (Anak Agung Ketut Agung, 1992: 192). This 26hectare temple (pura) is considered a symbol of harmony between Islam and Hinduism. Once a year, this location hosts the Topat War festival as a sign of reconciliation between the two religions that dates back to ancient times. Initially, the Topat War (Perang Topat) festival was initiated by a propagator of Islam named Sheikh Abdul Malik to reconcile groups in the Sasak tribe who like to fight. In this regard, the Topat War festival is a substitute for a real war between the groups and symbolizes peace (Ahmad Sodli: 2010).

The Topat War festival expresses gratitude to God and ensures that human lives should be happy, harmonious, and loving. It is usually held before the planting season and after the rainy season. Later, on the night of the full moon, Hindus perform the Pujawali ritual to commemorate the celebration or anniversary of Pura Lingsar. At the same time, Muslims celebrated Raden Mas Sumilir, an Islamic preacher from Demak, Central Java, who spread Islam in Lombok in the 15th century. The annual Topat War festival serves a variety of purposes. As cited by Suprapto (2015), Harnish asserts that the purposes include at least four: as a (1) mode of communication with God, (2) prayer for soil fertility, human well-being, blessings, rain, and restoration, (3) pride in 
the historical heritage of Hindus and Muslims while also developing socioreligious identities, and (4) means of adapting to current and future needs by learning from the past (Suprapto, 2015).

According to Erni Budiwanti, the Topat War festival is a war of peace that unifies Sasak tribe and Hindu communities in harmony and peace. It is instrumental in establishing tolerance, specifically between the Sasak tribe and Hindu communities. The festival spawns religiosity and shares beliefs between the Sasak and Hindu groups (Ni Putu Sinta Dewi, 2018). It symbolizes Indonesian unity and contributes to the promotion of Lombok as a multicultural community that is diverse yet integrated (Erni Budiwanti, 2014). The uniqueness of the culture serves as the glue that holds Muslims and Hindus, especially farmers, together in meaningful ways. This gesture of cooperation and unity transcends race and faith (Ahmad Sodli, 2010).

Following the Topat War festival, Hindus perform a Pujawali ritual at the Gaduh Temple, typically accompanied by a makemit or a three-night stay. Meanwhile, in Kemalik, Sasak Muslims did the same thing. The festival lasts about an hour. However, the entire ritual procession had occurred two days before the festival and portrayed true religious harmony between Hindus and Muslims. The day before the festival's height, the Lingsar people stage the 'Ngeliningan Kaok' procession, in which they parade two buffaloes around the Pura Lingsar complex.The Hindu and Muslim communities supply buffaloes slaughtered for religious purposes, and the meat is shared. This is another sign of tolerance. Cows are sacred to the Hindu community, and pork is forbidden to Muslims; however, both religions allow buffalo to be used. As a result, Islamic and Hindu groups do not permit to carry beef to Pura Lingsar. If such a rule is not followed, they may get pemaliq, a negative effect (interview with Ketut Sudi: 2018).

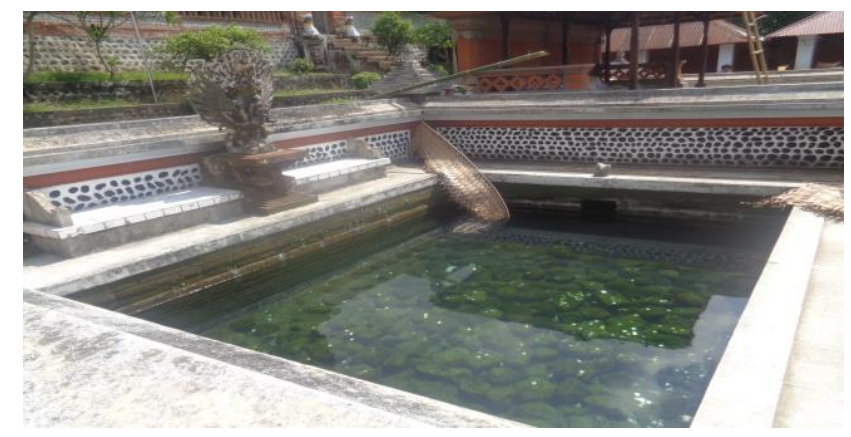

(Picture 3: Kemalik Spring in the Pura Lingsar) 
The entire Topat War festival procession is intended to express all appreciation to God Almighty for the blessings bestowed during the year. This is inextricably linked to the Langser Spring, which is located adjacent to the Pura Lingsar complex. For decades, the residents of Lingsar have believed that the spring is originated from the stick of Raden Mas Sumilir, a 15th-century Islamic preacher in Lombok. With that spring, farmers in Lingsar can plant and harvest rice on a year-round basis. Mr. Ramlan, the kemalik guard, said in an interview, "this place has been a place of worship for all religions: Islam, Hinduism, and Chinese people in Lombok, since I was a child." Indeed, both Christians and Buddhists use this Kemalik as a place of worship. Muslims use it to read lontar for one month as a sign of gratitude to Allah Almighty after harvest, and parents in the old days used it to cut back the belt after 'ngurisang' (aqiqah) or circumcision. Additionally, the Chinese create a place of worship, which is believed to bring blessings. Some believe that water at this spring location can cure disease.

This location is named 'Kemalik,' from 'malik' meaning sacred. Behind Kemalik is a temple called Gaduh Temple, the Lombok's oldest temple. Hindus worship behind this temple. According to an interview with Mr. Wayan (2018), some Muslims and Hindus regard Kemalik as a sacred place capable of curing all types of conditions. He continued, "When I was a boy, this place was quiet. But, once the temple was opened to the public, and became crowded. The Kemalik's structure is no longer original; it was renovated a year ago. If you wash there, you must use a white cloth."

Indeed, the Muslim tradition of Puja Wali and Perang Ketupat (Topat War) and the Hindu tradition of Wadalang are regular processions. Here, the Puja Wali coincides with the Hindu ritual ceremony at the Pura Lingsar, where Hindus are invited as guests. For Muslims, the Puja Wali is a festival until now popularized only in Bali. Puja Wali and Topat War (Perang Ketupat) festivals occur at the same time with Rarak Kembang Waru (fall flower). This hibiscus flower serves as a marker for the start of the Topat War (Perang Ketupat) festival. The flower is once abundant in this region, but it is now rare.

\section{Implications of Religious Symbols for Socio-Religious Life in Lombok}

According to Clifford Geertz, religion is based on symbolic practices as a cultural structure to create, intensify, and make these practices inviolable by secular revelation. Religious experience will impart the metaphysical image they create and the lifestyle they develop - so that this lifestyle becomes a 
religious act, leading the adherent to create rituals from an analytic point of view. Religious symbols are assumed to be religious beliefs expressed orally and are based on beneficial spiritual guidance. The mood serves as an excuse that religious objects are used as symbols in society and media to meet and observe one another. The living world and the imaginary world are transformed into the same world in a ritual when combined in religious symbols (Clifford Geertz, 1993: 112)

This research also discusses the relationship of religious society by using interactionism theory. Kimball Young and Raymond W. Mack argue that social interaction is the key to all social life because, without social interaction, there would be no shared life (Soerjono Soekanto, 2001: 67). Furthermore, John J. Macionis (2008) states that social interaction is how individuals behave and react in relationships with other individuals (John J. Macionis, 2008: 144). Based on these definitions, it is obvious that social interaction is a reciprocal relationship between two or more human individuals. The ideas, views, and behaviors of one individual influence each other, change or improve the other individual, or vice versa.

Furthermore, legends and myths still exist in Lombok between adherents of Islam and Hinduism, known as metaphysical theology. In its subjective context, this word is used as a religious formative. Legends and myths are used to translate faith, arguing that man must construct abstract beliefs into the modernization of society for his followers to absorb religion. As a result of the Islamization of Hinduism, Muslims and Hindus in Lombok share cultural similarities. Aside from that, there are places of worship for two different religions close by.

The philosophy of reciprocal regard for all faiths is taught by the nature of all religions' teachings. Interfaith pluralism and interfaith ties become fundamental teachings of each religion. Pluralistic learning is expressed by representations of pluralism attached to sacred places such as places of worship. On the other hand, the symbol was once a kind of competitive spirit among those preaching the teachings of their respective religions. However, in today's culture, where there is no longer any rivalry in religion, these places are seen as a form of religious fellowship and peace.

According to Geertz, the root of the symbol indicates that man is a symbol species, so he analyzes culture through his scientific experience and then matches it to the applicable law after analyzing the culture by tracing the 
meaning conveyed through the cultural communication process. Intercultural contact, according to Lustig and Koester (1993), is a mechanism of symbolic perception and transaction (Alo Liliweri, 2018: 653)

Intercultural contact is one way to communicate between religions. In Lombok's context, the interfaith group then made a symbolic interpretation with the form of statues of religious figures in Mayura Park and Pura Lingsar. Then, after the symbols are decided, religious people participate in joint activities (transactions). Some see the pluralism symbols attached to the place of worship as the embodiment of the structure established by public figures during the reign of the Kingdom of Bali and Islam. These places of worship have been restored and are now used as places of daily activity.

Similarly, Pura Meru, located next to the Mosque, is considered a symbol of religious unity. Falah Mosque near Pura Meru was built after Pura Meru. The mosque turned out to be a calming spirit between Hindus and Muslims. These groups see it beneficial for the peace of the community around temples and mosques. In this sense, Islam's acceptance of these symbols is characterized by Ethnoculture empathy, which depicts personal feelings towards various ethnic and cultural groups. Quintana (1994) describes ethnic empathy as a capacity for cognitive development gained during a person's life (Alo Liliweri, 2018: 38).

Islamic ethnocultural empathy is shown by the assumption that the religious symbols in Pura Lingsar are a sign of harmony between Muslims and Hindus. Some Muslims and Hindus around the temple also feel united. The tradition of the Topat War at Pura Lingsar has become a sign of religious peace. Despite the fact that it exists between two religions with different understandings, the Topat War ritual, which focuses on the knowledge to get closer to the Almighty, has united them (Suparman Jayadi, 2017).Meanwhile, according to Anna Maccowiak's study, the Topat War is a religious festival involving Balinese Hindus and Balinese Muslims, a famous tourist event with interesting interpretations, exotic and spectacular characters, as well as government support to a tourism event. Relations between religions have a long history, with religious figures at the forefront. The proof can be seen in Pura Mayura's Balairung or Berugak (meeting place), where statues of interfaith figures honor each other (observations: 2018). 
Pura Mayura and Pura Lingsar are considered symbol of pluralism embodiment by society initiated by religious community leaders in the past when the Balinese kingdom was in power. This worship place is used as a symbol in the past time and preserved as local wisdom in present time also. A symbol system is a religious, mythological development that is purposefully created to translate a much larger and complex reality. It's a dialectical development of religious and cultural values that reduces something abstract to something simplistic and easy to understand. Religious mythology can function as a metaphor. Since literal interpretation would make religious problems unreasonable, religious symbols should not interpret literally.

It is understandable if a faith prefers to use symbols to communicate its teachings. Since religion is a mixture of form and substance that cannot be separated, similar to skin and material, it is essential to note that the symbol is not a reality because there is an essence behind it. These symbols are significant in avoiding religious disputes. These symbols are a form of cultural solidarity. If the symbol is threatened, other religious people will believe that their faith is corrupted and considered contrary to the religious character (Mohammad Abu Nimer, 1998).

The Pura Meru, which is adjacent to the mosque, has become a recognized symbol of religious unity. The Mosque al-Falah, which is located near Pura Meru, was constructed following the completion of Pura Meru. The mosque was constructed to bridge the religious divisions between Hindus and Muslims. Finally, the group expressed its commitment to spiritual harmony in Pura Meru and Al-Falah Mosque. Mayura, Pura Meru, and Nurul Falah Mosque exemplify a kind of tolerance fostered for centuries by Islamic and Hindu figures. The Hindu Klodan village and Al-Falah mosque are places of worship for Cakranegara market traders. These regions are spread around Mataram, including Sekarbela, Karang Genteng, Karang Sukun, Sweta, and Cakranegara.

The majority of them are cloth traders, household appliance traders, and worship-necessities traders. These traders live side by side in the Cakranegara market. They connect without the use of any particular religious barriers. Hindu shopkeepers who converted to Islam and vice versa have been discovered. The researcher, for example, discovered older women in the village of Klodan who said: "I am a descendant of Islam, and I come from a Muslim household." 
Soleman B. Taneko (1984) explains the characteristics of social interaction, among others: (1) the presence of two or more perpetrators, (2) the existence of reciprocal relationships between perpetrators, (3) the process begins with the existence of social contact, either directly (primary social contact), or indirectly (secondary social contact), (4) the existence of a dimension of time (past, present, and future) that determines the nature of the ongoing reciprocal relationship, and (5) the purpose of each perpetrator (Soleman B. Taneko, 1984:10). Social contact is a mutual relationship between individuals and other individuals, and individuals and groups. People should process social interaction in such a way that it creates a pattern of relationships. Social contact may also be assumed by what Weber refers to as an individual's subjectively guided social behavior toward others (Johnson, Doyle Paul, 1986: 214).

These symbols have an impact on the relationship between Islam and Hindus. The effect of those symbols is associative social relations awakening the unity and solidarity of group members. Forms of cooperation between Muslims and Hindus include 1) forms of harmony, such as cooperation activities, discussion, and helping each other. For instance, they collaborate to construct a house and deliberate on the committee for a neighborhood case. 2) Bargaining is a type of collaboration that results from the negotiation or compromise of two or more parties to reach an agreement. The associative relationship is expressed in the following:

a) trade, the intense contact between the Islamic and Hindu communities on the market, and b) marriage or family relations. Interfaith marriages are a close family relationship between Islam and Hinduism around the Nurul Falah mosque and Pura Meru, c) Friendship between coworkers with intensive interaction. The form of tolerance of religious life between Muslims and Hindus awaken and strengthen the relationship enormously between religious believers and maintain good relations between religions because each religion teaches the values of togetherness of differences between religions.

The existence of religious pluralism symbols in Cakranegara and Lingsar shows that cultural differences from religions are not a conflict resource but rather a source of harmonious cultural dynamics. The Pura Lingsar has been considered by Muslim and Hindus communities as a symbol of togetherness between Muslims and Hindus built by the two religions in the past. Hence, togetherness is still felt by some Muslim and Hindu communities 
around it. A Tradition of Topat War festival, which is held on the court of Pura Lingsar, becomes a symbol of harmony in religious life. Even though their existence has a different understanding, it can build togetherness among the communities.

Friendship and communication between religions are manifested through a ritual ceremony called the Topat War festival. The event aims to obtain safety, prosperity, fertility, and gratitude to their ancestors and God Almighty. Ceremonial of the Topat War festival can guide and direct the life of the people of Lombok because it has ethical, aesthetic, and logical values for the community. Therefore, the festival needs to be maintained and preserved to implement cultural, religious, harmony, cooperation, and tolerance practices (Wayan Wirate: 2018).

As the majority religion adopted by the people in Cakranegara and Lingsar, Islam highly respects the beliefs of other religions. This fact shows that Islam nurtures other adherents and provides comfort for other religions. Islam also gives space for other religions to establish places of worship, in addition to their places of worship. In this study, the researcher sees Balinese Hinduism as the oldest religion followed by the rulers and kings in ancient times. The religion has also provided space for other religions to establish worship places and their places of worship. This phenomenon can be seen in the Nurul Falah mosque near Pura Meru. Similarly, the church near Taman Mayura was founded around the 1960s, long after the founding of Pura Mayura.

Unlike the case with Pura Lingsar, Kemalik is a symbol that shows religious competition between Hindus and Muslims because they both claim that Kemalik is a historical place for the spread of Islam in Lombok. The competition is manifested in the wars of diamonds; that is, wars that lead to peace, wars that are not painful, wars in an atmosphere of excitement, which ultimately bring blessings to the crops of the two religions.

This phenomenon shows that there has been interaction between the said religions from generation to the next. This also indicates that the interaction has its roots and its own history for the people around Pura Lingsar. The surrounding community later confirmed the history as a symbol of togetherness in socio-religious life. At the moment, these symbols seem to have little value (less mythical and less magical) because other religions are more rational than Hinduism today. 


\section{Conclusion}

This present study aimed to investigate the meaning of religious symbols in Lombok, West Nusa Tenggara, and their role in maintaining socioreligious harmony in the region. This investigation shows that the symbols of religious pluralism are obvously visible on the Pura Meru (next to the Nurul Falah mosque), on the statues of various religious figures at the Pura Mayura, and on the Pura Lingsar, a home for an ancient building called Kemalik. These symbols have been recognized as common properties of Hindus and Muslims and as places to get blessings. In addition, the Topat War festival is another legacy of Muslim and Hindu traditions. Those pluralism symbols are believed to be able to foster togetherness and harmony in Lombok, West Nusa Tenggara. They have colored the socio-religious life in Lombok and been a practice until now. The symbols indicate religious maturity and social harmony. This study also confirms that each religion in the said regions takes care of one another and respects places of worship. In general, these findings imply that religious symbols in Lombok, West Nusa Tenggara, reflect not only cultural interaction but also cultural solidarity. 


\section{Rerefernce}

Agung, Anak Agung Ketut.(1991). Kupu-Kupu Kuning Yang Terbang di Selat Lombok, Denpasar: PT.Upada Sastra.

Ambary, Hasan Muarif. (1998) Menemukan Peradaban Jejak Arkeologis dan Historis Islam Indonesia, Jakarta: Logos Wacana Ilmu.

Bogdan, Robert C dan Sari Knopp Biklen. (1982). Qualitative Reseach for Education an Introduction to Theory and Method, (boston: Allyn and Bacon Inc.

Budiwanti, Erni. (2014). Balinese Minority Versus Sasak Majority: Managing EthnoReligious Diversity And Disputes In Western Lombok, dalam Jurnal Heritage of Nusantara, Vol. 3 No. 2 December.

Creswell, J. W. . (1998). Qualitatif Inquiry and Research Design. Sage Publications, Inc: California.

Dewi, Ni Putu Sinta, Ni Gst. A.A Nerawati, I Gst Putu Gede Widiana.(2018). Eksistensi Pura Lingsar Dalam Dinamika Toleransi Antar Umat Beragama Di Nusa Tenggara Barat (Perspektif Filsafat Hindu) dalam Jurnal Penelitian Agama Hindu, Vol. 2 No.1 .

Geertz, Clifford. (1993). Religion as a cultural system. In: The interpretation of cultures: selected essays, Geertz, Clifford, Fontana Press.

Guide Book Lombok Sumbawa Nusa Tenggara Barat, Mataram : Dinas Kebudayaan dan Pariwisata NTB, 2015.

Harnish, D. (2006). Festivals and Cultures of Lombok. In Bridges to the Ancestors: Music, Myth, and Cultural Politics at an Indonesian Festival (pp. 16-43). University of Hawai'i Press. Retrieved April 9, 2021, from http://www.jstor.org/stable/j.ctt6wqswd.5

Hasil Observai pada tanggal 12 Nopember 2018

https://www.researchgate.net/profile/Anna_Mackowiak/publication/310450546_Int ernational_Tourism_and_Local_Religious_Traditions_on_Two_Indonesian _Islands/links/582d9e6908ae138f1c0194ao.pdf

https://www.researchgate.net/profile/Suparman_Jayadi/publication/334062410_Soc ial_Integration_between_Islam_and_Hindu_Adherents_through_Perang_T opat_Tradition_in_West_Lombok_Indonesia/links/5d1cocb392851cf440601e4 f/Social-Integration-between-Islam-and-Hindu-Adherents-through-PerangTopat-Tradition-in-West-Lombok-Indonesia.pdf

Jayadi, Suparman. (2017).Rasionalisasi Tindakan Sosial Masyarakat Suku Sasak Terhadap Tradisi Perang Topat (Studi Kasus Masyarakat Islam Sasak Lombok Barat), Jurnal Sosiologi Agama, Vol. 11, No. 1, Januari-Juni 2017.

Johnson, Doyle Paul, (1986).Teori Sosiologi Klasik dan Modern, jilid I, Jakarta: Gramedia.

Liliweri, Alo. (2016). Konfigurasi Dasar Teori-Teori Komunikasi Antar Budaya, Bandung: Nusa Media. 
Liliweri, Alo. (2018). Prasangka, Konflik dan Komunikasi Antarbudaya, Jakarta: Kencana, 2018

Macionis, John J., (2008). Sociology 12th ed. Pearson Prentice Hall.

Marshall, Chaterine and Gretchen B. Rossman, (1989). Designing Qualitatif Research, Sage Publication.

Mohammed Abu Nimer. (2010). Nirkekerasan dan Bina Damai dalam Islam, Teori dan Praktik, Penerjemah: M. Irsyad Rhafsadi dan Khairil Azhar, Jakarta: Demokrasi Project.

Nasir, M. A. (2020). Conflict, Peace, and Religious Festivals: Muslim-Hindu-Christian Relations on the Eastern Indonesian Island of Lombok. Interreligious Studies and Intercultural Theology, 4(1), 102-123. https://doi.org/10.1558/isit.36471

Pak Ramlan berusia 53 tahun adalah penjaga kemalik, orang tuanya secara turun temurun bertugas sebagai penjaga dan petugas kebersihan tempat tersebut.

Parimartha, I Gde (2014). Lombok Abad XIX, Politik, Perdagangan, dan Konflik di Lombok 1831-1891, Denpasar: Pustaka Larasan.

Ritzer, George .(2008). Teori Sosiologi , terj. Nurhadi, Yogyakarta: Kreasi Wacana, 2008

Sodli, Ahmad. (2010). Revitalisasi Kearifan Lokal Dalam Masyarakat Multikultural Di Kecamatan Lingsar, Lombok Barat, NTB, Jurnal "Analisa" Volume XVII, No. 02, Juli - Desember.

Soekanto, Soerjono. (2001). Sosiologi Suatu Pengantar, Jakarta: RajaGrafindo Persada.

Suprapto. (2015). The Theology of Tolerance in Hindu and Islam: Maintaining Social Integration in Lombok - Indonesia, Jurnal Ulumuna Vol 19 No 2 (2015): December

Suprapto. (2017). Sasak Muslims And Interreligious Harmony Ethnographic Study Of The Perang Topat Festival In Lombok - Indonesia, Journal Of Indonesian Islam Volume 11, Number 01, June .

Taneko, Soleman B. (1984). Struktur dan Proses Sosial. Jakarta: CV. Rajawali.

Turner, Bryan S. (2012). Relasi Agama dan teori Sosial Kontemporer, terj. Inyiak Ridwan Muzir, Jogjakarta: IRCiSoD, 2012.

Van der Kraan, Alfons (2009). Lombok: Penaklukan, Penjajahan dan Keterbelakangan, 1870-1940, terjemahan, M. Dony Supanra, Mataram: Lengge Printika, 2009

Wawancara dengan H. Syahdan Ilyas pada tanggal 16 Nopember 2018

wawancara dengan Jaz'in Hamid pada tanggal 20 Oktober 2018

Wawancara dengan Ketut Sudi pada tanggal 19 Nopember 2018

Wawancara dengan Muhammad pedagang disekitar Pure dan Masjid, pada tanggal 13 Nopember 2018.

Wawancara dengan Muslihun Anggota FKUB Propinsi NTB pada tanggal 5 Nopember 2018 
Wawancara dengan Nyoman masyarakat disekitar Pure Meru dan Masjid pada tanggal 13 Nopember 2018.

wawancara dengan pengayah pure I Gede Remba pada hari Kamis tanggal 6 September 2018

Wawancara dengan Tokoh Agama Hindu Wirate pada tanggal 9 Nopember 2018

Wawancara dengan Wayan pada tanggal 27 Nopember 2018

Wirata, Wayan. (2015). Inter-cultural Communication between Local Hindu and Islamic Community in Perang Topat Ceremony in Pura Lingsar, Narmada District, Lombok, Indian journal of arts, 5(13) 